\title{
AKU CINTA LOVINA: PERAN SASTRA DALAM MEMPROMOSIKAN PARIWISATA BALI UTARA
}

\author{
Gde Artawan \\ Universitas Pendidikan Ganesha Singaraja \\ Email: gartawan@yahoo.com
}

\begin{abstract}
The development of tourism in North Bali is indebted to literary writers and works, but their contributions are rarely realized. Lovina Beach which was the center of the growth of North Bali tourism was originally introduced in the 1970s by writer Panji Tisna, later by Sunaryono Basuki who wrote several stories set in Lovina. This article analyzes the novel Aku Cinta Lovina (I Love Lovina, 2017) by Sunaryono Basuki to show aspects of the story that promote North Bali tourism. The novel is examined with a literary approach to tourism, with a focus on how the novel portrays the tourist attraction of Lovina and the relationship between the host and guest. The results of the analysis show that the novel Aku Cinta Lovina shows the strong reciprocal relationship between literature and tourism, where the writer promote tourism, at the same time the writer get inspiration from tourism. Besides being intense in promoting North Bali tourism, this novel also portrays a harmonious relationship of host and guest that reinforces Balinese hospitality which is an important attraction of Bali tourism.
\end{abstract}

Keywords: North Bali, host and guest, Lovina, literary tourism, hospitality

\section{Pendahuluan}

Pariwisata Bali mulai dikembangkan tahun 1920-an oleh pemerintah kolonial Belanda. Saat itu, Pelabuhan Buleleng merupakan salah satu pintu masuk utama ke Bali (Vickers 2012; Picard 1996; Astiti 2018). Pada awalnya, perkembangan pariwisata Bali berpusat di Bali Utara, namun sesudah kemerdekaan, episentrum perkembangan pariwisata Bali terjadi di Bali Selatan. Hal ini terjadi menyusul perpindahan ibukota Provinsi Bali dari Singaraja ke Denpasar, dan pembangunan fasilitas pariwisata di Bali selatan seperti Bandar Udara Ngurah Rai, pelabuhan Benoa, dan Hotel Bali Beach di Sanur. Sejak itu, perkembangan pariwisata di Bali Utara agak melambat, dan 
Pelabuhan Buleleng yang dulu sebagai pintu masuk Bali yang terpenting, tidak lagi seaktif dulu menerima kunjungan kapal dagang, penumpang, atau wisata.

Meski demikian, dengan pelan tetapi pasti, pariwisata Bali Utara juga berkembang dengan kian populernya pantai Lovina. Pantai ini dipopulerkan oleh sastrawan Bali, AA Nyoman Panji Tisna. Dia juga dikenal sebagai pengarang Angkatan Pujangga Baru menyusul karya-karyanya yang terkenal seperti Ni Rawit Ceti Penjual Orang (1935), Sukreni Gadis Bali (1936), I Swasta Setahun di Bedahulu (1938), dan beberapa karya lainnya. Panji Tisna adalah keturunan Raja Buleleng yang awalnya tinggal di Desa Bunut Panggang mengelola kebun kelapa dan bisnis kopra ayahnya, kemudian sejak 1940 pindah ke Lovina, menempati tanah orang tuanya. Di Lovina yang tenang ini, tepat pada Hari Natal 1953, dia menulis novel I Made Widiadi kembali Kepada Tuhan (terbit 1957). Pelan tapi pasti, Lovina kian terkenal. Nama Lovina menimbulkan beberapa tafsir, namun yang paling populer adalah 'Love Indonesia' (Putra 2013; Caldwell 1985).

Sejak Panji Tisna tinggal di sana, popularitas Lovina kian mencuat, melalui berbagai pemberitaan media massa yang mengaitkan dengan nama besar kepengarangannya. Selain itu, tentu saja Lovina dan pantai di sepanjang itu, terkenal sepi, hening, tenang dan cocok untuk tempat berlibur. Lovina kemudian dilengkapi dengan semakin banyak fasilitas akomodasi dan fasilitas wisata lainnya. Kehadiran ikan lumba-lumba di pagi hari di pantai Lovina dan sekitarnya, menambah daya tarik Lovina. Wisatawan asing pun kian banyak datang dan berlibur di Lovina. Tahun 1980-an, Lovina banyak menjadi paket wisata yang dikemas dengan paket tur di Kuta, Candidasa (Karangasem), dan Lovina. Wisatawan Australia dan Eropa senang berlibur di Lovina, dan dari sana mereka berjalan-jalan melihat daya tarik wisata di kota Singaraja seperti Gedong Kirtya (Perpustakaan Lontar yang didirikan zaman Belanda), Pelabuhan Buleleng dan Kampung Cina, dan desa-desa tua di Kecamatan Banjar. 
Perkembangan Lovina menyerupai apa yang terjadi di Kuta, di mana banyak homestay yang dikelola penduduk setempat. Selain itu, banyak terjadi kontak antara wisatawan dan warga lokal, khususnya di kawasan pantai. Kontak itu umumnya terjadi antara laki-laki lokal dengan turis perempuan yang terkadang berlanjut dalam kisah cinta sesaat, biasanya dikenal dengan kisah cinta seumur visa. Laki-laki lokal kadang sudah berkeluarga, memiliki istri dan anak, tetapi kerap terperangkap dalam jalinan cinta dengan wisatawan, di mana laki-laki Bali sering diberikan sebutan gigolo, walaupun kadang-kadang kabur kapan mereka menjadi pemandu wisata sesungguhnya atau kapan sampai melakukan hubungan seksual dengan wisatawan (Jennaway 1998; 2002).

Novel Aku Cinta Lovina (2017) karya Sunaryono Basuki adalah salah satu karya sastra yang dilukiskan terjadi di Lovina. Novel ini pun melukiskan hubungan yang intens antara pegawai hotel laki-laki Bali dengan turis perempuan cantik dari Inggris yang berlibur di Lovina. Lebih dari sekadar percintaan atau persahabatan yang hangat antara host and guest (tuan rumah dan tamu), terminologi dalam antropologi pariwisata yang merupakan pertemuan tempat terjadinya kontak budaya antara orang dalam dan orang luar (Smith dan Brent 2001).

Artikel ini menganalisis aspek-aspek cerita novel Aku Cinta Lovina dalam mempromosikan pariwisata Lovina pada khususnya, Bali Utara pada umumnya. Kajian dilakukan dengan mengkaji representasi beberapa aspek dari destinasi wisata Lovina dalam novel dan bagaimana lukisan relasi antara host dan guest dan apa makna lukisan itu dalam promosi pariwisata Bali Utara pada khususnya dan Bali pada umumnya.

Sejauh ini, belum ada kajian atas novel ini karena karya ini relatif baru, terbit 2017. Ada satu ulasan ringkas yang dimuat di sebuah blog dan karena ringkas dan ditulis dengan gaya populer membahas beberapa aspek permukaan seperti tema dan alur (Sugiarta 2018). Uraian tersebut tidak menyentuh aspek pariwisata sama sekali. 
Hal ini bisa dipahami karena pendekatan sastra pariwisata merupakan pendekatan baru di Indonesia. Kebaruan analisis ini terletak pada kajian novel dengan pendekatan pariwisata dan mengajukan area baru dalam kolaborasi kajian sastra dan kajian pariwisata sehingga memberikan kontribusi baru kepada kedua bidang tersebut pada khususnya dan pada studi interdisipliner humaniora pada umumnya.

\section{Teori dan Metode}

Kajian ini menggunakan teori sastra pariwisata (literary tourism) yang belum lama diperkenalkan di Indonesia. Putra (2019) membatasi bahwa sastra pariwisata adalah kajian terhadap karya sastra dengan memperhatikan aspek-aspek kepariwisataan. Batasan ini bersumber dari definisi tentang literary tourism yang diberikan oleh Busby dan Klug (2001 dalam Hoppen dkk 2014) yang menjelaskan bahwa:

Literary tourism occurs when authors or their literature become so popular that people are drawn to either those locations associated with the author (e.g. birthplace, home, graveside) or those featured within their writings.

Kutipan tersebut berarti bahwa sastra pariwisata terjadi kalau ada penulis atau karyanya menjadi terkenal dan orang-orang tertarik berkunjung ke sana, ke tempat lahirnya, ke makamnya, ke rumahnya, atau ke tempat-tempat yang dilukiskan dalam karyanya. Ada banyak contoh karya sastra yang mempromosikan pariwisata, seperti Laskar Pelangi (Hirata 2005) dan Eat Pray Love (Gilbert 2006). Kedua novel ini diangkat ke layar lebar menjadi film dengan judul sama sehingga perannya sebagai saran promosi pariwisata menjadi lebih luas.

Berdasarkan pengertian ini, Putra (2019) merumuskan ada empat fokus kajian sastra pariwisata. Keempat kajian itu adalah (i) tourism themes yaitu tema-tema pariwisata dalam karya sastra, (ii) literary figure, literary place yaitu kajian atas sosok sastrawan dan tempat-tempat yang berkaitan dengannya yang menjadi daya tarik 
wisata; (iii) literary events, activities, yaitu peristiwa sastra dan aktivitas sastra lain yang berkaitan dengan kepariwisataan; dan (iv) ecranisation yaitu alih wahana sastra ke dalam film yang mengandung potensi promosi pariwisata. Yang terakhir ini jelas bisa dilihat dalam film Laskar Pelangi yang mempromosikan pariwisata Bangka Belitung dan Eat Pray Love mempromosikan pariwisata Itali, India, dan Bali.

Keempat fokus kajian itu tidak selalu berdiri sendiri tetapi bisa juga kombinasi, antara tema dan tempat. Dalam kajian terhadap novel Aku Cinta Lovina, pendekatan sastra pariwisata dikombinasikan antara kajian tematik dan literary places, dalam hal ini tempat yang dilukiskan dalam novel, yaitu destinasi wisata Lovina. Pendekatan sastra yang digunakan untuk membantu sastra priwisata adalah kajian instrinsik, representasi, dan point of view (sudut pandang).

Penelitian ini merupakan kajian kualitatif interpretif, yang menjadikan data dalam teks sebagai unit analisis. Novel dibaca dengan teknik close reading (pembacaan dekat) dengan mencatat unsur-unsur yang hendak dikaji yaitu representasi teks atas aspek kepariwisataan Lovina (alam, sosial, hospitality), dialog antar-tokoh, dan sudut pandang (point of view). Data-data kualitatif ini diinterpretasikan untuk menentukan tema cerita dan kaitannya dengan literary places kepariwisataan dalam novel.

\section{Hasil dan Pembahasan}

Dalam hasil dan pembahasan diuraikan tiga hal, yaitu gambaran umum perkembangan pariwisata Bali Utara dengan fokus Lovina dan sekitarnya, sepintas tentang profil pengarang Sunaryono Basuki, dan analisis sastra pariwisata novel $A k u$ Cinta Lovina.

\section{Perkembangan Pariwisata Bali Utara}

Perkembangan pariwisata Bali Utara dan daerah lain di Indonesia bermula sejak tahun 1920-an, ketika Indonesia masih dijajah Belanda. Pariwisata Bali memang merupakan inisiatif pemerintah kolonial Belanda. Pada awal pariwisata Bali 
berkembang di Bali Utara, peran Pelabuhan Buleleng sangat penting (Vickers 2012; Picard 1996; Astiti 2018), karena lewat pelabuhan inilah wisatawan datang dengan kapal laut dari Jawa, atau dalam perjalanan menuju/kembali dari Sulawesi. Selain mengangkut hasil bumi, kapal yang singgah di Pelabuhan Buleleng juga mengangkut penumpang umum, dan wisatawan. Yang termasuk penumpang umum misalnya, warga Bali yang akan pergi ke Jawa, misalnya untuk melanjutkan sekolah di Surabaya, atau kelompok pemain Komedi Stamboel yang datang dari Jawa untuk pentas di Bali dan Makassar (Putra 2008). Pada zaman kolonial, Bali Utara menjadi episentrum perkembangan pariwisata di pulau ini. Banyak daya tarik wisata budaya terdapat di Buleleng yang dikunjungi wisatawan, seperti permandian Air Sanih dan Pura Meduwe Karang terletak di Banjar Tegal, Desa Kubutambahan. Perpustakaan lontar Gedong Kirtya yang dibangun tahun 1929 juga menjadi salah satu daya tarik wisata budaya waktu itu. Lovina belum populer pada zaman kolonial. Pada akhir 1920-an, perusahaan kapal dagang Belanda KPM mendirikan Hotel Bali di Jalan Veteran Denpasar, dan Pelabuhan Benoa menjadi pintu masuk untuk wisatawan ke Bali Selatan.

Sesudah Indonesia merdeka, perkembangan pariwisata terpusat di Bali Selatan. Presiden Sukarno mendirikan Hotel Bali Beach di Sanur 1963-1966, pemerintah juga mengembangkan bandar udara Ngurah Rai sebagai pintu masuk ke Pulau Dewata akhir 1960-an. Popularitas dan daya tarik Bali yang kuat, membuat perkembangan pariwisata Bali semakin kuat ke Bali Selatan. Namun kemudian, melimpah juga ke Bali Utara. Mulai tahun 1970-an, Pantai Lovina mulai dikenal sebagai tempat yang hening dan tenang untuk berlibur. Akomodasi mulai bermunculan di daerah Lovina.

Akhir 1980-an, perkembangan Lovina sangat pesat. Wisatawan Australia dan dari Eropa banyak yang berlibur ke Lovina. Lovina segera mejadi pusat pertumbuhan pariwisata Bali Utara. Lovina menjadi semacam Kuta kedua-nya Bali. Walau pantai ini berpasir agak hitam, tapi daya tariknya tetap kuat. Atraksi menonton ikan lumba- 
lumba (dolphin) menambah daya tarik wisata Lovina. Banyak turis yang ingin menonton lumba-lumba jumpalitan di air pagi hari, saat mentari terbit, akhirnya pergi ke Singaraja dan menginap sehingga pagi hari bisa melakukan Dolphin Tour. Puri Singaraja juga merupakan daya tarik wisata yang memperkuat daya tarik wisata budaya Bali Utara (Andiani 2014).

Sejalan dengan pertumbuhan pariwisata Bali Selatan, pariwisata Bali Utara juga ikut berkembang. Mulai awal 1990-an, beberapa daerah di Bali Utara menunjukkan diri sebagai titik-titik perkembangan baru. Setidaknya ada dua titik pertumbuhan selain Lovina, yaitu Munduk dan Pemuteran. Munduk lokasinya berdekatan dengan daerah wisata Bedugul, Kebun Raya, dan Danau Beratan, berhawa sejuk dan menjadi pilihan bagi ekspatriat di Bali Selatan untuk berakhir pekan. Lama-lama, Munduk memiliki pasar tersendiri selain expat. Di antara akomodasi yang populer di sini adalah Puri Lumbung dan Munduk Moding Plantation. Daerah pertumbuhan kedua adalah Desa Pemuteran dengan daya tarik pantai terutama karena taman karang laut. Daerah ini menarik banyak penyelam. Seiring dengan itu, hotel-hotel mulai bermunculan di Pemuteran, seperti Matahari Beach Hotel dan Puri Taman Sari. Belakangan perkembangan melebar ke Pulau Menjangan, yang mulai banyak mendapat kunjungan dan mulai tersedia akomodasi berkelas di sana.

Dengan titik perkembangan baru, Bali Utara menunjukkan kemampuannya mengembangkan pariwisata mengikuti kemajuan Bali Selatan. Walaupun tidak mungkin akan mengejar kemajuan Bali Selatan, yang jelas pariwisata Bali Utara ikut berkembang. Sampai tahun 2019, jumlah kamar hotel non-bintang di Singaraja sudah mencapai 5,663 buah. Jumlah hotel berbintang mencapai 20 buah. Lovina yang awalnya tumbuh dengan akomodasi sederhana, kini banyak menawarkan akomodasi yang baik. Paling tidak kelas bintang tiga ke atas. Hotel kelas budget juga muncul di pusat kota. Semua meneguhkan kian tumbuhnya pariwisata Bali Utara. Di Pelabuhan Celukang Bawang sesekali hadir kapal pesiar membawa wisatawan asing untuk 
berwisata di Bali Utara, antara lain melihat desa tua di Kecamatan Banjar dan daya tarik wisata lainnya.

Bali Utara setidaknya memiliki 84 daya tarik wisata yang beragam termasuk peninggalan sejarah (Widiastini dkk 2012; Astiti 2018). Di antara titik-titik pertumbuhan pariwisata, Lovina tetap paling ramai dan berhasil menarik wisatawan dari berbagai negara, seperti Australia, Eropa, dan Amerika, walau tidak sebanyak dan membludak Bali Selatan.

Dalam perkembangannya yang mulai ramai itulah, Lovina memberikan inspirasi kepada sastrawan untuk menulis karya sastra, termasuk penulis Sunaryono Basuki yang menulis novel Aku Cinta Lovina. Berikut dikisahkan sedikit latar belakang pengarang untuk membantu pemahaman karyanya dengan pendekatan kajian sastra pariwisata.

\section{Penulis dan Karyanya}

Novel Aku Cinta Lovina dikarang oleh Sunaryono Basuki, pengarang kelahiran 9 Oktober 1941 di Kepanjen, Malang. Pengarang ini adalah sosok yang menarik dalam dunia sastra dan dunia akademik. Dia adalah dosen Fakultas Bahasa dan Seni di Undiksha Singaraja, berpangkat profesor. Sebagai profesor, dunia sehari-harinya adalah dunia akademik yang mengutamakan logika. Sebagai pengarang, dia bergelut dengan dunia estetik yang mengutamakan rasa dan keindahan. Meskipun tampak kontradiktif, Sunaryono berhasil memadukan kedua profesinya dengan baik, sampai pensiun sebagai dosen, dan sampai meninggal sebagai pengarang. Sunaryono meninggal 20 Desember 2018, dalam usia 78 tahun, dan tidak pelak lagi, kolega dan mantan muridnya merasa kehilangan tokoh kreatif (Piscayanti 2019).

Karya-karya Sunaryono, baik berupa cerpen maupun novel, terbit di media terkemuka seperti Kompas, Bali Post, dan majalah sastra Horison. Dia juga menulis puisi dan diterbitkan dalam antologi puisi, seperti Anak Negeri (1967) dan Opo Iyo Roh Little Miss Nobody (1983). Minatnya menulis sudah muncul sejak lama, dan 
berkembang terus di tengah kesibukannya sebagai dosen. Bukunya yang telah terbit Scarf Merah Hati (Rosda, 1986), Hunus (Balai Pustaka, 1991), Siti Nurjanah (Balai Pustaka, 1993), Maut di Pantai Lovina (Gramedia, 1993), Di Sudut Hyde Park (Balai Pustaka, 1994), Dadong Sandat (Balai Pustaka, 1994, cetak ulang pada tahun 2000), Ompong (Grafikatama, 1995), Bumi Hangus (Pustaka Jaya) dan Rangda (Indonesia Tera, 2001), Peter Hilang (Balai Pustaka, 2001), Topeng Jaro Ketut (2001). Novel Aku Cinta Lovina diterbitkan Balai Bahasa Denpasar tahun 2017 (Ensiklopedia Kemdikbud 2020). Ini merupakan novelnya yang terakhir.

Jika melihat karyanya, banyak yang dilukiskan dengan setting di luar negeri khususnya Inggris. Ini terjadi karena Sunaryono dulu pernah kuliah di Inggris untuk mengambil gelar master. Selain latarnya di luar negeri, tokoh-tokohnya pun kebanyakan orang asing. Pengalaman hidup di Inggris waktu kuliah dan kemampuan berbahasa Inggris yang memungkinkan dia untuk menulis dengan ciri khas latar luar negeri dan tokoh orang asing. Ketika harus melukiskan tempat dan ungkapan tokoh, Sunaryono tidak menghadapi kesulitan karena dia melukiskan daerah, budaya, dan bahasa Inggris yang dikuasainya. Tidak banyak pengarang yang memiliki keberuntungan pernah hidup di luar negeri seperti Sunaryono. Pengalaman sekolah di luar negeri dan tinggal di Singaraja yang dekat dengan daerah wisata Lovina, memberikan peluang baginya menimba inspirasi untuk menciptakan karya-karya sastra yang khas. Selalu mudah dibuktikan bahwa pokok naratif novel senantiasa memiliki hubungan tekstual yang dekat dengan wacana sosial dan tempat di mana pengarang berinterelasi di dalamnya (Artawan, 2018).

Kekhasan lain dari karya Sunaryono adalah memotret dinamika budaya Bali dengan kacamata orang non-Bali tetapi menikah dengan perempuan Bali. Dalam posisi demikian, dia bukan sepenuhnya orang luar Bali, tetapi juga tidak sepenuhnya orang Bali. Pengetahuannya tentang adat dan budaya Bali menjadi sangat memadai baginya untuk menyusun cerita dengan kisah adat dan budaya Bali yang kadang bersanding atau berlawanan dengan adat dan budaya Barat, dalam konteks 
kepariwisataan. Selain itu, sebagai orang Jawa, dia juga familiar dengan budaya Bali karena banyak nilai kepercayaan yang sama, seperti tentang tuah keris, seperti terungkap dalam novel Hunus.

\section{Promosi Pariwisata Bali Utara dalam 'Aku Cinta Lovina'}

Novel Aku Cinta Lovina mengisahkan hubungan dekat antara seorang laki-laki Bali dan keluarganya dengan seorang perempuan Inggris yang pernah menjadi turis yang berlibur di Lovina. Tokoh laki-lakinya bernama Putu Suarcaya dan adiknya Kadek Citra, sedangkan perempuan Inggris bernama Caroline dan orang tuanya $\mathrm{Mr}$ dan Mrs Watson. Hubungan Putu dengan Caroline cukup intim, sampai berciuman dan mengucaokan cinta tetapi tidak sampai ada hubungan badan. Hubungan mereka menjadi hubungan kekeluargaan, setelah Caroline menyekolahkan Kadek Citra ke Inggris, sampai berhasil menajdi doktor. Saat wisuda, Putu dan orang tuanya datang menyaksikan ke London. Di sana cerita diakhiri dengan pesan bahwa segala yang berawal dari kebaikan akan berakhir dengan kebaikan. Dalam melukiskan daerah tujaun wisata, novel tidak saja memuji tetapi juga memberikan kritik dan ulasan. Pembaca novel ini tidak saja akan mendapatkan kisah cinta antara tokoh-tokohnya tetapi juga gambaran kritis tentang pariwisata Bali, khususnya pariwisata Bali Utara.

Novel ini dapat dikatakan sebagai sastra pariwisata karena alasan berikut. Pertama, cerita dilukiskan terjadi di daerah wisata yaitu Lovina. Kedua, tokohnya bekerja di hotel (Putu) dan menikmati pelayanan akomodasi di Lovina (Caroline). Ketiga, isi novel banyak mengisahkan hubungan host (Putu) dan guest (Caroline), antara pegawai hotel dan wisatawan, walau kemudian berlanjut ke hubungan pribadi yang cinta. Keempat, novel mempromosikan banyak objek wisata seperti Lovina sendiri, Candidasa, Kuta, Pura Meduwe Karang di Singaraja, dan Tulamben di Karangasem. 
Dalam ulasan populer yang dibuat di blognya sendiri, Sugita (2018) menyampaikan bahwa Sunaryono menggarap Aku Cinta Lovina dengan teknik bertutur sederhana, nyaris tanpa gaya. Justru inilah ciri khas penulis senior dari Bali Utara yang mengaku hanya sebagai tukang ketik dari cerita-ceritanya. Sugita berpendapat:

Lewat novelnya kita tidak hanya disuguhi lanskap Bali yang demikian rinci tetapi juga keluasan wawasan dan pengalaman hidupnya. Mencantumkan nama pelaku dan latar tempat yang sebenarnya serta tahun berlangsungnya kejadian juga menjadi warna tersendiri dari novel-novelnya, sehingga sulit bagi kita untuk membedakan mana kejadian nyata dan mana rekaan.

Dalam ulasannya itu, Sugita sama sekali tidak menyinggung tentang sastra pariwisata. Namun, secara akurat dia menyebutkan bahwa menang benar bahwa tidak saja nama tempat yang disebutkan secara sebenarnya dalam novel ini, tetapi juga nama-nama orang seperti A.A. Udayana P. Tisna yang merupakan salah seorang putra AA Panji Tisna (p.2), Dr. Gede Artawan, kebetulan penulis sendiri (p.103), penyair Umbu Landu Paranggi (p. 103), dan Prof. Dr. Ketut Seken, M.A. (p.115), dosen di Undiksha yang merupakan teman Sunaryono.

Cerita diawali dengan kisah Putu yang bekerja di hotel Putri Duyung di Lovina. Di bagian awal, ada ulasan mengenai arti Lovina, dengan menunjukkan beberapa tafsir. Lewat ungkapan Putu, begini novel menuliskan pengertian Lovina:

Menurut A.A. Udayana P. Tisna di dalam bukunya yang berjudul Pahlawan Nasional Patih Jelantik, Seorang Bangsawan Buleleng, yang diterbitkan Grafiti. Lovina bermakna 'cinta dan hormat terhadap sesama' yang mengesankan sebagai pembukaan tirai dunia baru menuju peralihan globalisasi. Lovina didirikan pada tanggal 15 April 1954. Dan A.A. Udayana adalah salah seorang putra A.A. Panji Tisna. Entah yang mana yang benar, dan setiap turis asing yang bertanya mengenai hal itu, selalu kujawab dengan pilihan itu dan biasanya mereka puas dengan keyakinan masing-masing (p.2). 
Cara Sunaryono menjelaskan Lovina menurut sudut pandang Putu merefleksikan gaya penulis akademik memberikan ulasan sebuah topik. Hal ini tidak mengherankan, karena Sunaryono sendiri adalah seorang akademik.

Sebagai destinasi wisata, novel melukiskan bahwa Lovina lebih memberikan ketenangan dibandingkan Kuta yang terlalu ramai, seperti dilukiskan berikut:

Para wisatawan asing yang berkunjung ke Lovina mengidamkan ketenangan dan ketenteraman yang mereka tidak bisa peroleh di Kuta, yang terletak di Bali Selatan. Menurut pendapat seorang wisatawan asing sempat aku tanyai, Kuta sudah menjadi negara asing di bumi Bali (p.2).

Selain berbagai kelebihan destinasi wisata Lovina, novel ini juga melukiskan hubungan harmonis antara host and guest, dalam hal ini Putu dan Kadek Citra, dan Caroline dan orang tuanya. Caroline dikisahkan menginap di hotel tempat Putu bekerja. Dia jatuh cinta, dan ingin sekali tidur bersama Putu. Mereka sempat intim, saling berciuman di kamar, tetapi tidak sampai melakukan hubungan seks. Caroline dilukiskan memiliki libido agresif, tetapi Putu tidak menyambut dengan alasan hukum karma, yaitu dia takut kalau-kalau nanti adiknya ditiduri orang sampai hamil. Insiden ini seolah menguatkan kesan bahwa cewek bule selalu bersifat bebas dan gampang dalam berhubungan seks, sementara laki-laki Bali menghayati nilai agama. Putu adalah tokoh yang dilukiskan pengarang sebagai sosok yang menolak stereotipe bahwa laki-laki Bali yang bekerja di dunia pariwisata adalah orang yang senang memanfaatkan kesempatan untuk petualangan seks dengan tamu, tertarik berburu wisatawan asing.

Lukisan stereotipe mudah dalam urusan seksual, tokoh Barat juga dilukiskan sebagai orang yang kaya dan murah hati dalam memberikan uangnya. Caroline dilukiskan memiliki banyak uang, mungkin karena ayahnya Mr Watson adalah seorang pengacara. Caroline memberikan sejumlah uang kepada Putu seolah dalam motif untuk membeli cinta. Misalnya, Caroline memberikan Putu uang untuk 
membeli ipad. Namun, ternyata stereotipe wanita Barat memberikan uang untuk membeli cinta, tidak sesempit itu. Caroline memilliki jiwa mulia, buktinya dia mengajak Kadek Citra untuk kuliah ke Inggris, sampai benar-benar lulus jenjang doktor di Leed University. Saat hari wisuda, Putu dan kedua orang tuanya diundang oleh keluarga Caroline ke Inggris, seperti lukisannya berikut ini.

...kami berangkat ke Inggris dengan bekal tambahan beberapa ratus pound selain surat rekomendasi dari Mr Watson. Ternyata Kadek tidak ikut menjemput kami di Heathrow.Yang menjemput Caroline.

Di sana Caroline mencium tangan ayah, mencium pipi ibu, dan mencium bibirku (p. 157).

Kalimat terakhir dalam kutipan di atas menjelaskan hubungan antara Caroline dengan Putu dan keluarganya. Caroline mencium tangan ayah Putu, mencium pipi ibu Putu, dan mencium bibir Putu. Hubungan respek dan hubungan kasih yang terjalin dalam adegan yang menunjukkan harmonisnya hubungan host and guest, kali ini Caroline sebagai host, sedangkan Putu dan orang tuanya sebagai guest.

Novel ini ditutup dengan mengutip ungkapan pujangga William Shakespeare yaitu "All's well that ends well" (p.158) yang berarti bahwa segala kebaikan yang berakhir baik. Sebuah ungkapan universal yang menemukan relevansi makna dalam hukum karma, yaitu perbuatan baik akan berakhir dengan baik. Secara keseluruhan, novel ini juga memancarkan kesan bahwa orang Bali bersifat ramah dan pandai bergaul, hangat, jujur, dan menghargai tamu. Novel ini, dengan demikian, bisa dikatakan melukiskan keramahan orang Bali yang menjadi modal pengembangan pariwisata. Salah satu alasan wisatawan asing datang ke Bali karena keramahtamahan orang Bali, yang tampak dalam praktik hospitaliti atau pelayanan di berbagai lini jasa pariwisata. Selain masalah Bali Utara indah memiliki beberapa objek wisata, novel ini pada intinya melukiskan orang Bali ramah tama (friendly), sifat yang sangat penting dalam dunia hospitaliti. 


\section{Simpulan}

Artikel ini membahas bagaimana novel Aku Cinta Lovina sebagai media untuk mempromosikan keberadaan pariwisata di Bali Utara pada khususnya dan Bali pada umumnya. Nilai promosi pariwisata itu tampak pada dua hal. Pertama, lukisan lanskap indah Lovina dan daerah tujuan wisata lainnya di Bali Utara. Kedua, lewat lukisan ramah-tamah orang Bali yang membuat wisatawan yang berlibur di Lovina merasa puas dan nyaman. Dengan kata lain, kesan orang Bali friendly sangat kuat dalam novel ini.

Kajian atas novel ini dengan pendekatan sastra pariwisata memberikan tafsir alternatif dari arus utama kajian sastra yang bersifat intriksik dan ekstrinsik denagn fokus nilai-nilai dan pesan moral dalam konteks sosial seperti kasta. Novel Aku Cinta Lovina pun memiliki nilai-nilai sosial, namun konteksnya adalah dunia kepariwisataan.

Melihat kisah, isi, dan latar novel Aku Cinta Lovina, kajian sastra pariwisata memberikan kontribusi tidak saja kepada kajian sastra, tetapi juga kajian pariwisata. Kajian ini bisa dijadikan sebuah bukti bahwa sastra mendapat inspirasi dari pariwisata dan pada saat yang sama, novel seperti Aku Cinta Lovina juga menjadi semacam promosi bagi pariwisata Lovina khususnya dan Bali Utara pada umumnya.

\section{Daftar Pustaka}

Andiani, Nyoman Dini, Ni Made Ary Widiastini, Nyoman Trisna Herawati. 2014. "Pengembangan Puri Agung Singaraja Sebagai Daya Tarik Wisata Sastra", Prosiding Seminar Nasional Riset Inovatif II, Tahun 2014, pp. 691-696.

Artawan, Gde. 2018. Menembus Patriarki, Refleksi Perjuangan Perempuan Bali dalam Novel Indonesia. Jakarta: RajaGrafindo.

Astiti, Ni Komang Ayu. 2018. “Optimalisasi Pengelolaan Pelabuhan-Pelabuhan Kuno Di Buleleng Dalam Pengembangan Pariwisata", Forum Arkeologi, Volume 31, Nomor 1, April 2018, pp. 75 - 92. 
Basuki, Sunaryono. 1993. Maut di Pantai Lovina. Jakarta: Gramedia Pustaka Utama.

Basuki, Sunaryono. 2017. Aku Cinta Lovina. Denpasar: Balai Bahasa Bali.

Caldwell, Ian. 1985. "Anak Agung Panji Tisna, Balinese Raja and Indonesian novelist, 1908-78", Indonesia Circle 36:55-60.

Ensiklopedia Kemdikbud.

2020.

http://ensiklopedia.kemdikbud.go.id/sastra/artikel/Sunaryono_Basuki_Koesn osoebrotoEnsiklopedia Sastra Indonesia - Badan Pengembangan dan Pembinaan Bahasa, Kementerian Pendidikan dan Kebudayaan Republik Indonesia. Akses 27 Mei 2020.

Gilbert, Elizabeth. 2006. Eat Pray Love. New York: Penguin Books.

Hirata, Andrea. 2005. Laskar Pelangi. Yogyakarta: Bentang:

Hoppen, Anne, Lorraine Brown, Alan Fyall. 2014. “Literary tourism: Opportunities and challenges for the marketing and branding of destinations?", Journal of Destination Marketing E Management 3 (2014) 37-47.

Jennaway, Megan. 1998 'Passage frustrated; Alice's looking-glass and the gendered access to global domains of knowledge in rural North Bali'. Paper, Conference: Asia in Global Context, University of New South Wales, Sydney, 28 September1 October.

Jennaway, Megan. 2002. Sisters and Lovers: Women and Desire in Bali. US, Lexington: Rowman \& Littlefield.

Picard, Michel. 1996. Bali; Cultural Tourism and Touristic Culture. Singapore: Archipelago Press.

Piscayanti, Kadek Sonia. 2019. “Drama Ini Tak Akan Berakhir - Obituari Sunaryono Basuki Ks.", https://tatkala.co/2019/12/21/drama-ini-tak-akan-berakhirobituari-sunaryono-basuki-ks/ Akses 27 Mei 2020.

Putra, I Nyoman Darma. 2008. “Modern Performing Arts as a Reflection of Changing Balinese Identity", Indonesia and the Malay World, Volume 36, No. 104, pp. 87114.

Putra, I Nyoman Darma. 2008. "Modern Performing Arts as A Reflection of Changing Balinese Identity", Indonesia and the Malay World, 36:104, 87-114, DOI: 10.1080/13639810802017842

Putra, I Nyoman Darma. 2013. “Kaitan antara Biografi, Proses Kreatif, dan Karyakarya Panji Tisna", Pustaka, Vol. XIII, Nomor 2, Agustus 2013, pp. 15-161. 
Putra, I Nyoman Darma. 2019. “Literary Tourism: Kajian Sastra dengan Pendekatan Pariwisata", dalam I Wayan Pastika dkk (eds), Nuansa Bahasa Citra Sastra Pendalaman dan Pembaruan dalam Kajian Bahasa dan Sastra, pp. 161-180. Denpasar: Pustaka Larasan.

Smith, Valena and Maryann Brent (eds). 2001. Hosts and Guests Revisited: Tourism Issues of the 21st Century. New York: Cognizant Communication Corporation

Sugiarta, Ketut. 2018. "Dendang Cinta dari Utara", https://ketutsugiartha.wordpress.com/ Akses 27 Mei 2018.

Vickers, Adrian. 201. Bali A Paradise Created. Singapore: Tutle.

Widiastini, Ni Made Ary, Nyoman Dini Andiani, Trianasari. "Strategi Pemasaran Pariwisatadi Kabupaten Buleleng, Bali", Jurnal Ilmu Sosial dan Humaniora, Vol.1, No.1, April 2012, pp. 1-19.

\section{Profil Penulis}

Gde Artawan lahir di Klungkung, 20 Februari 1959. Dosen di program studi Pendidikan Bahasa dan Sastra Indonesia Universitas Pendidikan Ganesha, lulusan progran doktor (S3) Linguistik Universitas Udayana tahun 2010. Menerima Anugerah Seni Wija Kusuma dua kali dari pemerintah Buleleng, tahun 1998 dan tahun 2007. Kumpulan cerpennya "Petarung Jambul" mendapat Anugerah Seni Widya Pataka dari Pemerintah Propinsi Bali tahun 2008. Buku karya sastranya terhimpun dalam buku 'Kaki Langit' (1984). 'Buleleng dalam Sajak (1996), “Kesaksian Burung Suksma” (1996), “Spektrum” (1997), “Tentang Putra Fajar" (2001), “Puisi Penyair Bali” (2006), “Cinta Disucikan, Kehidupan Dirayakan” (2007). “Dendang Denpasar, Nyiur Sanur" (2012), “Singa Ambara Raja dan Burung-Burung Utara" (2013), kumpulan puisi “Tubuhku Luka Pesisir, Tubuhmu Luka Pegunungan” (2014), antologi puisi/sekaligus sebagai kurator “Klungkung : Tanah Tua, Tanah Cinta" (2016), antologi “Madah Merdu Kamadhatu”(2017), buku puisi “Hatimu Sebatang Pohon” (2017). Buku teksnya terbit berjudul Menembus Patriarki: Refleksi Perjuangan Perempuan Bali dalam Novel Indonesia (2008). 